\title{
In situ backfilll monitoring database
}

\author{
J Oke RockEng Inc., Canada
}

A Hashemi RockEng Inc., Canada

\begin{abstract}
The history of backfilling underground mined-out voids dates back to the beginning of mining several centuries ago using rockfill. Currently, there are three major types of backfill: rock, hydraulic, and paste fill. When backfill is required to be exposed from mining beside or underneath, cement binder is added. Cemented hydraulic fill is the most commonly used backfill as it has existed for over 80 years. In the early 1960s, a series of field instrumentations were initiated by the US Bureau of Mines on hydraulic fill. These studies were conducted in order to better understand the characteristics of hydraulic backfill.

Cemented paste backfill (CPB) has gained wider acceptance in the mining industry and the number of operations utilising CPB has expanded significantly. One of the earliest attempts at field measurement in CPB occurred over 20 years ago. Since then, extensive scientific research has been conducted on CPB material in order to provide mines with a rational design process; however, there has been limited published instrumentation programs. The authors' affiliated company has been involved with in-stope backfill instrumentation programs at numerous operations. Because of the data collection and field experience, the authors have a better understanding of how in situ backfill behaves, and how operations can use this information to safely improve the efficiency of their backfilling operation. In order to improve the safety and efficiencies of backfilling for other mines and other practitioners, a collection of published data along with additional case studies are provided. This paper summarises both hydraulic and CPB instrumentation results focusing on the important mechanical properties of backfill: time to onset of effective stresses and hydrostatic loading (i.e. fluid backfill to soil-like material), influences of flushes, thermal expansion and contraction, and influences of seismic and blast events.
\end{abstract}

Keywords: paste, hydraulic, backfill, instrumentation, thermal expansion/contraction

\section{Introduction}

The history of backfilling underground mined-out voids dates back to the beginning of mining several centuries ago (Potvin et al. 2005). Yumlu (2001) found that cemented paste backfill (CPB) costs account for 15-20\% of the total mining cost for an open stope mine. Currently there are three major types of backfill: rock (unconsolidated and cemented), hydraulic, and paste backfill. When backfill is required to be exposed through mining beside or underneath, cement binder is added. Binder is typically $75-80 \%$ of backfilling operations costs (Grice 1998). Alcott et al. (2019) found that optimising the cement binder in backfill, through instrumentation, at Casa Berardi mine resulted in a CDN 500,000 annual savings.

CPB has gained wider acceptance in the mining industry and the number of CPB operations has expanded significantly (Belem et al. 2004; Le Roux et al. 2005; Thompson et al. 2014a). Extensive scientific research has been conducted on CPB material in order to provide mines with a rational design process. However, it is necessary to have a thorough understanding of the interaction between filling rate, consolidation rate, and cement hydration rate for each specific CPB material (Helinski et al. 2011). Grabinsky (2010) states that a rational design process has yet to be demonstrated as there is a lack of field monitoring programs to quantify the CPB performance.

In the early 1960s, a series of field instrumentations were initiated by the US Bureau of Mines. These measurements were performed in stopes filled with hydraulic fill (Yang 2016). One of the earliest attempts at field measurement in CPB occurred over 20 years ago. The affiliation of the authors' has been collecting 
and interpreting field instrumentation data specific to backfill since 2010. Grabinsky \& Bawden (2007) published data from an extensive campaign of in situ measurements of backfilling stopes. Since then, a better understanding of how in situ backfill behaves, and how operations can use this information to safely improve the efficiency of their backfilling operation, has been developed. This improvement is due to an ever-increasing catalogue of published field data. In order to continue this trend for mines and other practitioners, the authors have put together a collection of published data, as well as inclusion of additional case studies the authors' affiliated company was directly involved with. This paper summarises the instrumentation programs from both hydraulic backfill (CHB) and CPB, focusing on the important backfill behaviours: time to hydrostatic loading (i.e. fluid backfill to soil-like material), influences of flushes, thermal expansion and contraction, and influences of seismic and blast events.

\section{$2 \quad$ Backfill types}

As previously stated, there are three different types of backfill: rock, hydraulic, and CPB. The scope of this paper is on CHB and CPB. In general, backfill is placed at the top of an open void, with barricades constructed at all openings to contain the backfill, as shown in Figure 1.
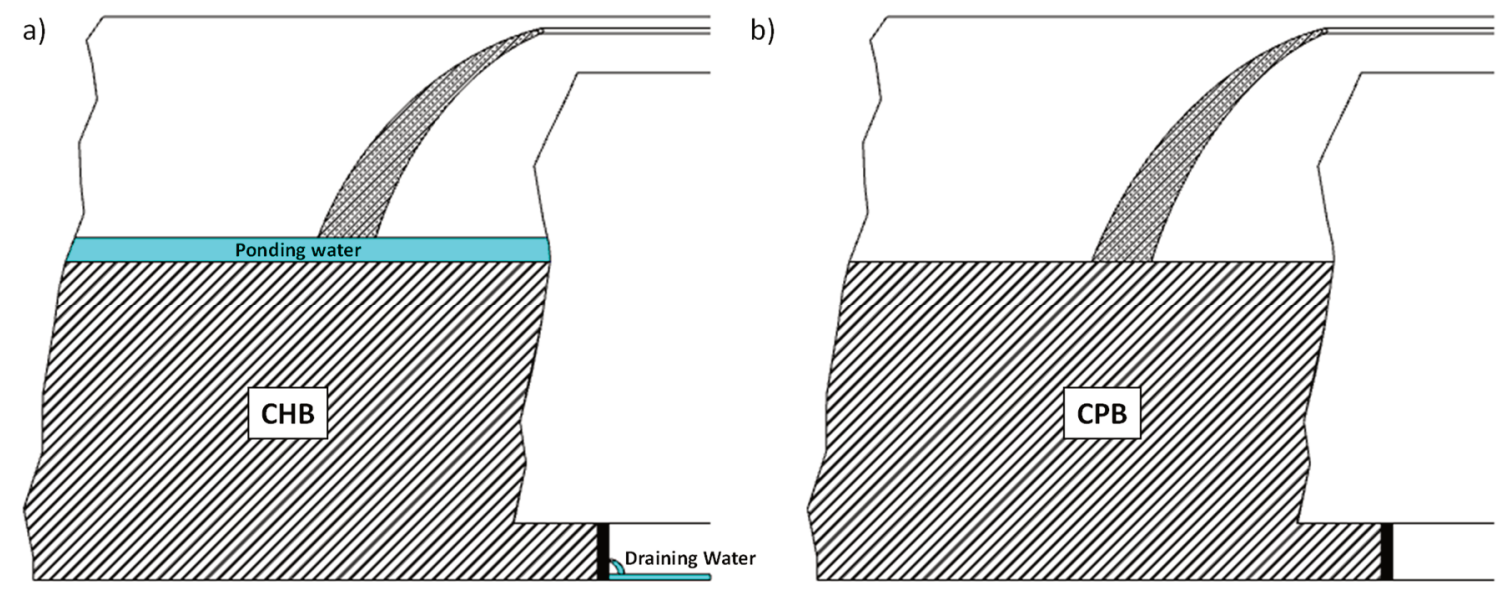

Figure 1 Illustration of placement of backfill. (a) Cemented hydraulic backfill (CHB); (b) Cemented paste backfill (CPB)

\subsection{Cemented hydraulic backfill}

According to Peele (1941, as cited in Yang 2016), hydraulic backfill had initially been used in coal mines in the USA since 1884. Hydraulic fill is defined as low solids content (normally 60-75\%) slurry, consisting of classified mill tailing and/or natural sand, transported through boreholes and pipelines to underground stopes (Hassani \& Archibald 1998; Potvin et al. 2005). Due to the hydraulic delivery, it contains a substantial amount of water that drains after placement; therefore, typical fill strategies for hydraulic fill require pour times with recurring resting time to drain the placed fill as well as having a barricade that is permeable, as shown in Figure 1a. Potvin et al. (2005) provides pouring and resting time regimes utilised at Mount Isa. The pour-rest time regime is a function of the following parameters:

- Hydraulic fill cure time.

- Hydraulic fill delivery rate.

- Hydraulic fill permeability rate.

- Rock mass permeability rate.

- Barricade wall drainage rate (including drainage pipes).

The hydraulic fill permeability and cure time parameters can be calculated or estimated. Yang (2016) stated that Australian hydraulic fills typically range from $2.8 \times 10^{-6}$ to $8.3 \times 10^{-6}$. However, before filling it is necessary 
to conduct laboratory tests to directly measure the hydraulic conductivity of CHB. Barricade wall drainage (Figures 1a \& 2) rate can be assessed during the initial plug pour. It should be noted that the plug may have to be poured in several stages, depending on the actual solid backfill rise rate realised in individual stopes.
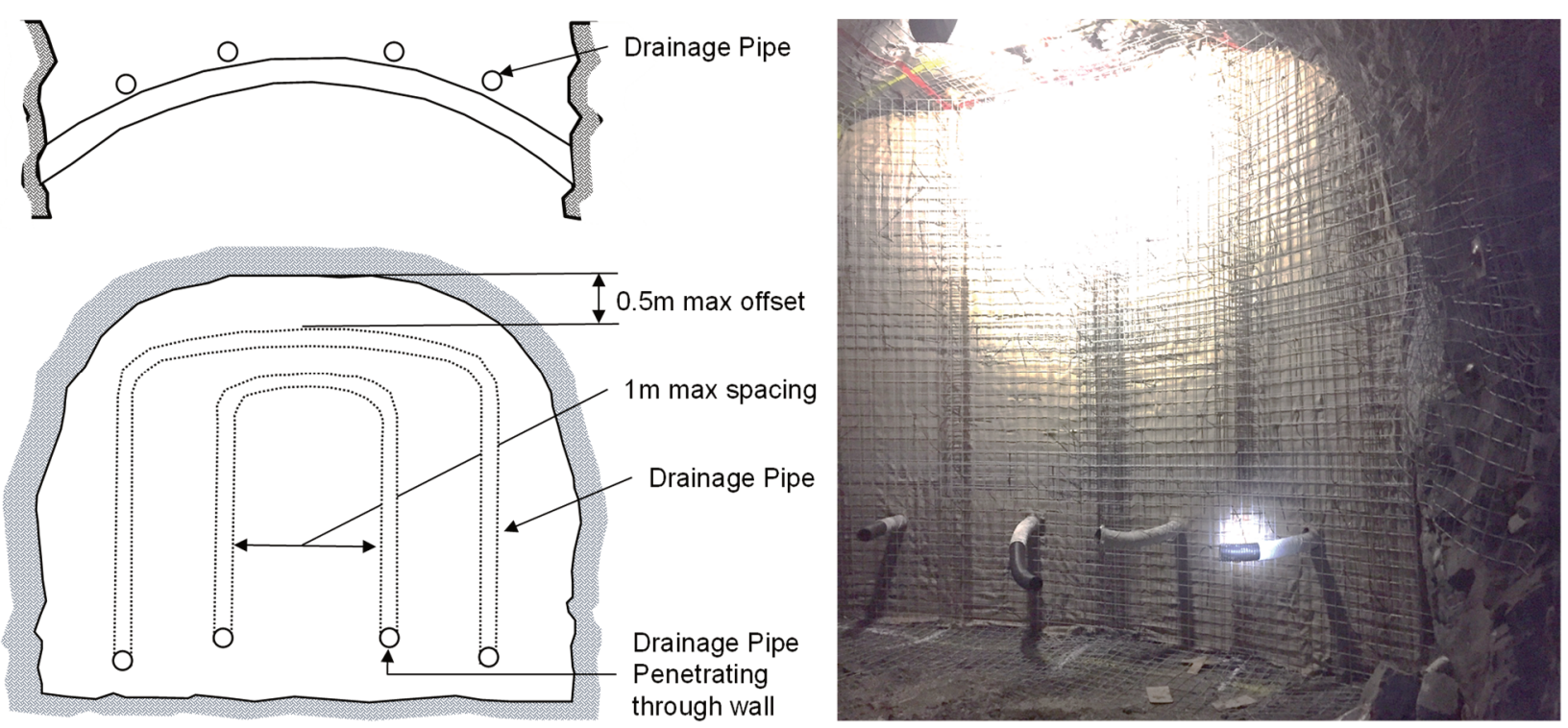

Figure 2 Illustration of typical barricade drainage mechanisms for $\mathrm{CHB}$

It is well known that hydraulic fills can experience grain size segregation, with the formation of a shallow angle bench sloping away from the fill point. The segregation is a result of differential settling rates based on particle sizes. The particle size segregation results in spatial variation in cement content, and so spatially distinct pressure and temperature responses for the interpreted coarse and fine grain zones need to be captured. This segregation has been identified in instrumentation data (Thompson et al. 2014b), and is assumed to be the cause of the lower temperature and lower pressure acting on the barricade as compared to the in-stope instrumentation for CHB.

\subsection{Cemented paste backfill}

CPB consists of cement and high-density thickened tailings which has a solid content (by weight) of 75-85\%. The cement hydration process induces a net reduction in volume, similar to that of 'self-desiccation' in concrete. The 'self-desiccation mechanism' results from the fact that the volume of the hydrated cement is less than the sum of the volumes of the unhydrated cement and the water used in the hydration process. Thus, the hydration process acts like an internal 'sink' for water (Helinski et al. 2011). Due to this process, $\mathrm{CPB}$ does not require a permeable barricade, and can contract.

The characteristic behaviour of the CPB is based on the chemical properties of the binder and the tailings. There are many different binders available for $\mathrm{CPB}$, with the most common being Portland cement. According to Le Roux et al. (2005) tailing properties consist of:

- Particle size distribution.

- Mineralogical composition.

- Plasticity.

- Partial shape. 


\section{Instrument backfill database}

Backfill studies have been taken place since 1961 (Table 1), which consist of backfill behaviour characteristics and/or instrumentation. Table 1 provides a summary of different mines which have published conducted backfill studies.

Table 1 Summary on backfill case studies (modified after Yang 2016). Reference in italics is cited from Yang (2016), and not verified by the authors at the time of this publication. Note: HB denotes hydraulic backfill (unclear if cemented or not); CPB denotes cemented paste backfill; CHB denotes cemented hydraulic backfill; and CRB denote cemented rock backfill

\begin{tabular}{lll}
\hline Reference & Backfill type & Mine, location \\
\hline McNay \& Corson (1961) & $H B$ & Mines of the Coeur d'Alene district in Idaho, USA \\
Corson \& Wayment (1967) & HB & Star mine, Idaho, USA \\
Corson (1971) & HB & Luck Friday mine, Idaho, USA \\
Askew et al. (1978) & HB & Broken Hill, Australia \\
Knutsson (1981) & HB & Nasliden mine, Sweden \\
Thibodeau (1989) & HB & Levack Mine, Canada \\
Hassani et al. (1998, 2001) & CPB & Chimo mine, Canada \\
Yumlu (2001), & & \\
Thompson et al. (2012) & CPB & Cayeli mine, Turkey \\
Ouellet \& Servant (2000) & CPB & Bouchard-Herbert mine, Canada \\
Harvey (2004) and & CPB & Doyon gold mine, Canada \\
Belem et al. (2004) & & \\
Le Roux et al. (2005) & CPB & Golden Giant mine, Ontario, Canada \\
Grabinsky \& Bawden (2007) & CPB & Williams mine, Canada \\
Thompson et al. (2009, 2011, etc.) & CPB & Kidd mine, Canada \\
Helinski et al. (2011) & CPB & Kanowna Belle mine, Australia \\
Helinski et al. (2011) & CPB & Savannah nickel mine, Australia \\
Thompson et al. (2012) & CPB & Cayeli mine, Turkey \\
Hasan et al. (2014) & CPB & Lanfranchi nickel mine, Australia \\
Thompson et al. (2014b) & CHB & Garson Ramp mine, Canada \\
Doherty et al. (2015) & CPB & Raleigh gold mine, Australia \\
Emad et al. (2015b) & CRB & Nickel mine located in Manitoba, Canada \\
Alcott et al. (2019) & CPB & Casa Berardi mine, Canada \\
Oke et al. (2021a, b) & CPB & Red Lake operations, Canada \\
\hline & & \\
\hline
\end{tabular}




\section{$4 \quad$ Backfill database}

The following database consists of instrumentation results from published and unpublished case studies. The database has been split into the two different backfill types.

\subsection{Cemented hydraulic backfill}

Table 2 provides a summary of the CHB instrumentation results.

Table 2 Summary of CHB studies. H1 denotes pressure acting on barricade. PP denotes porewater pressure. RLO $=$ Red Lake operations. New unpublished results that the authors have received permission to publish are denoted in italics

\begin{tabular}{|c|c|c|c|c|c|c|c|}
\hline Mine & Stope & $\begin{array}{l}\text { Width } \\
\text { (m) }\end{array}$ & $\begin{array}{l}\text { Length } \\
\text { (m) }\end{array}$ & $\begin{array}{l}\text { Height } \\
\text { (m) }\end{array}$ & $\begin{array}{l}\text { Binder } \\
\text { (\%) }\end{array}$ & $\begin{array}{l}\text { Plug pressure on } \\
\text { barricade (kPa) }\end{array}$ & $\begin{array}{l}\text { Max pressure on } \\
\text { barricade ( } \mathrm{kPa})\end{array}$ \\
\hline Coleman Mine & $\begin{array}{l}3510 \\
1610\end{array}$ & 15 & 21 & 27 & 10 & - & $131 \mathrm{H} 1 / 60 P P$ \\
\hline Coleman Mine & $\begin{array}{l}3510 \\
1612\end{array}$ & 15 & 21 & 27 & 10 & $81 H 1 / 36 P P$ & $295 H 1 / 153 P P$ \\
\hline Coleman Mine & $\begin{array}{l}3510 \\
1814\end{array}$ & 16 & 23 & 33 & 10 & $85 \mathrm{H} 1$ & $240 \mathrm{H} 1$ \\
\hline Garson Mine & $\begin{array}{l}880- \\
6515\end{array}$ & 8.2 & 27.8 & - & $3-3-6.7$ & 106H1/10PP & $152 \mathrm{H} 1$ \\
\hline Garson Mine & $\begin{array}{l}880- \\
6514\end{array}$ & - & - & - & - & $69 \mathrm{H} 1 / 18 \mathrm{PP}$ & $160 \mathrm{H} 1 / 15 \mathrm{PP}$ \\
\hline
\end{tabular}

\subsection{Cemented paste backfill}

Tables 3 and 4 provide a summary of the CPB instrumentation results. These results include a combination of typical pour regimes (i.e. plug pour and cure, followed by main pour, Table 3 ) and continuous pour regimes (i.e. poured with minimal interruptions, Table 4). 
Table 3 Summary of CPB plug pour-cure-main pour regime case studies. Notes: ${ }^{1}$ denotes final pressure acting on barricade, ${ }^{2}$ denotes pressure acting on barricade at the end of plug pour, ${ }^{3}$ denotes measure time within the brow or at barricade, $\mathrm{H} 1$ denotes pressure acting on barricade, PP denotes porewater pressure

\begin{tabular}{|c|c|c|c|c|c|c|c|c|}
\hline$\stackrel{\mathscr{E}}{\check{\Sigma}}$ & $\begin{array}{l}\frac{ \pm}{0} \\
\dot{0}\end{array}$ & 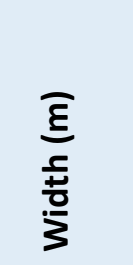 & 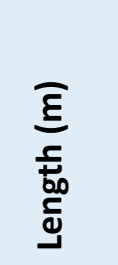 & 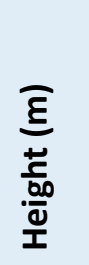 & $\begin{array}{l}\frac{\partial}{0} \\
\frac{0}{0} \\
\frac{0}{0} \\
\frac{0}{0} \\
\frac{00}{2}\end{array}$ & 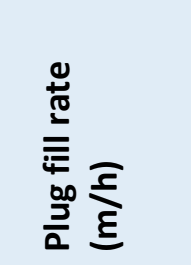 & 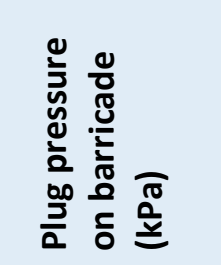 & 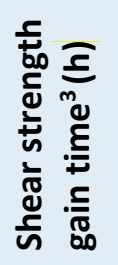 \\
\hline Cayeli mine & 715 & 10 & 15 & 15 & 6.5 & $0.35-0.42$ & $99 \mathrm{H} 1 / 50 \mathrm{PP}$ & - \\
\hline Williams mine & $\begin{array}{l}9415-55 \\
\text { Alimak stope }\end{array}$ & 5 & 30 & 149 & 3.0 & - & $36 \mathrm{H} 1$ & $6-8$ \\
\hline Kidd mine & $88-947$ & 11 & 18 & 40 & 4.5 & - & - & - \\
\hline $\begin{array}{l}\text { Kanowna Belle } \\
\text { mine }\end{array}$ & - & 15 & 18 & 40 & 3.1 & $0.2-0.5$ & - & - \\
\hline $\begin{array}{l}\text { Savannah nickel } \\
\text { mine }\end{array}$ & - & 10 & 12 & 23 & 2.7 & 0.04 & - & - \\
\hline $\begin{array}{l}\text { Lanfranchi nickel } \\
\text { mine }\end{array}$ & - & $11-17$ & $23-28$ & 40.6 & 3.8 & 0.7 & $37 \mathrm{H}$ & - \\
\hline Doyon gold mine & 8-1 FW & 11 & 21 & 29 & 7 & - & $34 \mathrm{H} 1$ & - \\
\hline Doyon gold mine & Unknown & 12 & 23 & 22 & 7 & - & $15 \mathrm{H} 1$ & - \\
\hline $\begin{array}{l}\text { Casa Berardi } \\
\text { mine }\end{array}$ & $\begin{array}{l}118-910- \\
2030-27 N\end{array}$ & - & - & - & 8 & 0.29 & - & $12-24$ \\
\hline Cayeli mine & S820 N07 & 8 & 13.6 & 17 & 7.4 & 0.35 & 50 & $\sim 5 \mathrm{~h}$ \\
\hline Cayeli mine & S880 S13P2 & 7 & 14.9 & 20 & 7.0 & 0.35 & 72 & $\sim 6 \mathrm{~h}$ \\
\hline Mine Z & $\begin{array}{l}\text { 55-9555 } \\
\text { Alimak }\end{array}$ & $3-5$ & 18 & 150 & 6.5 & 0.3 & - & $\sim 18 \mathrm{~h}$ \\
\hline
\end{tabular}


Table 4 Summary of CPB continuous pour regime case studies (i.e. poured with minimal interruptions). Notes: ${ }^{1}$ denotes final pressure acting on barricade, ${ }^{2}$ denotes pressure acting on barricade at the end of plug pour, ${ }^{3}$ denotes measure time within the brow or at barricade, $\mathrm{H} 1$ denotes pressure acting on barricade, PP denotes porewater pressure. RLO = Red Lake Operations

\begin{tabular}{|c|c|c|c|c|c|c|c|c|}
\hline$\stackrel{\mathscr{g}}{\Sigma}$ & $\begin{array}{l}\frac{ \pm}{0} \\
\dot{0}\end{array}$ & $\begin{array}{l}\overline{\mathbf{E}} \\
\frac{5}{5} \\
\stackrel{0}{0} \\
\vdots\end{array}$ & 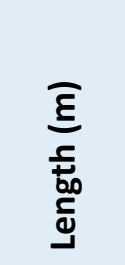 & 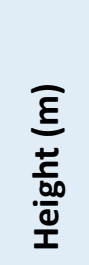 & 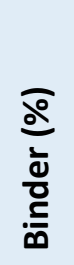 & 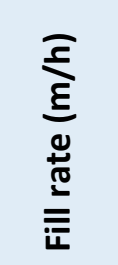 & 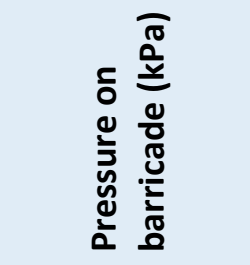 & 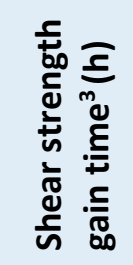 \\
\hline $\begin{array}{l}\text { Williams } \\
\text { mine }\end{array}$ & 9500 L70 5 & $7-9$ & $18-20$ & $\begin{array}{c}50- \\
55\end{array}$ & 3 & - & $\begin{array}{c}{ }^{1} 41 \mathrm{H} 1 \\
2 \sim 28 \mathrm{H} 1\end{array}$ & $\sim 6$ \\
\hline $\begin{array}{l}\text { Cayeli } \\
\text { mine }\end{array}$ & 685 & $\begin{array}{l}10- \\
12.5\end{array}$ & 25 & 16 & 8.5 & $\begin{array}{l}0.22- \\
0.25\end{array}$ & $\begin{array}{c}{ }^{1} 47 \mathrm{H} 1 / 5-7 \mathrm{PP} \\
242 \mathrm{H} 1\end{array}$ & 9 \\
\hline $\begin{array}{l}\text { Cayeli } \\
\text { mine }\end{array}$ & S860 S15 & 6 & 20 & 20 & 7.4 & 0.35 & ${ }^{1} 98$ & $\sim 8$ \\
\hline $\begin{array}{l}\text { Kidd } \\
\text { mine }\end{array}$ & 67-SL1 & 19 & 28 & 32 & 4 & $\begin{array}{c}0.26- \\
0.5\end{array}$ & $\begin{array}{l}{ }^{1} 65 \mathrm{H} 1 \\
{ }^{2} 50 \mathrm{H} 1\end{array}$ & $\sim 24$ \\
\hline Mine $X$ & $9560150-31$ & 7 & 15 & 68 & 3 & $\begin{array}{c}0.62- \\
0.75\end{array}$ & $\begin{array}{c}{ }^{1} 80 \mathrm{H} 1 \\
227 \mathrm{H} 1 / 7 \mathrm{PP}\end{array}$ & $2-3$ \\
\hline Mine $X$ & 9175-MZ1-77 & 8 & 20 & 30 & 8 & $\begin{array}{c}0.57- \\
0.63\end{array}$ & $\begin{array}{l}{ }^{1} 40 \mathrm{H} 1 / 15 \mathrm{PP} \\
{ }^{2} 23 \mathrm{H} 1 / 12 \mathrm{PP}\end{array}$ & $1-2$ \\
\hline Mine $X$ & 9170-MZ1-78 & 8 & 20 & 30 & 8 & $\begin{array}{c}0.5- \\
1.2\end{array}$ & $\begin{array}{l}{ }^{1} 82 \mathrm{H} 1 / 11 \text { PP } \\
{ }^{2} 45 \mathrm{H} 1 / 42 \mathrm{PP}\end{array}$ & $3.4-4.3$ \\
\hline Mine $Y$ & 2171 & 13 & 20 & 34 & 3.8 & 0.3 & $\begin{array}{l}{ }^{1} 61 \mathrm{H} 1 / 0 \mathrm{PP} \\
{ }^{2} 20 \mathrm{H} 1 / 8 \mathrm{PP}\end{array}$ & $<2$ \\
\hline RLO & $\begin{array}{l}321-865-1 \mathrm{~W} \\
\text { BLK3 }\end{array}$ & 3.0 & 23.5 & 16.4 & 5 & 0.4 & $\begin{array}{c}{ }^{1} 24 \mathrm{H} 1 \\
{ }^{2} 8 \mathrm{H} 1\end{array}$ & $\sim 2$ \\
\hline RLO & 260-876-1 BLK 1 & $\begin{array}{c}2.4- \\
3.4\end{array}$ & $\begin{array}{c}22.7- \\
26.5\end{array}$ & 20.6 & 5 & 0.3 & $\begin{array}{l}{ }^{1} 44 \mathrm{H} 1 \\
{ }^{2} 15 \mathrm{H} 1\end{array}$ & $\sim 4$ \\
\hline RLO & $\begin{array}{l}512-595-1 E \\
\text { BLK3 }\end{array}$ & $\begin{array}{c}3.4- \\
5\end{array}$ & $13-21$ & 24 & 9 & 0.3 & $\begin{array}{l}{ }^{1} 52 \mathrm{H} 1 \\
2 \sim 5 \mathrm{H} 1\end{array}$ & $\sim 3$ \\
\hline RLO & $\begin{array}{l}192-979-1 E \\
\text { BLK4 }\end{array}$ & $\begin{array}{c}3.0- \\
4.3\end{array}$ & $12-14$ & 20 & 9 & 0.3 & $\begin{array}{l}{ }^{1} 112 \mathrm{H} 1 \\
2 \sim 30 \mathrm{H} 1\end{array}$ & $\sim 5$ \\
\hline
\end{tabular}

\subsection{Additional case studies}

The authors have also been involved with other instrumentation programs not listed in Tables 2, 3 and 4. The excluded case studies do not use the typical barricade system, but employed novel containment structures. These novel structures resulted in irregular pouring practices that required different placement of instrumentation. Consequently, these measurements are not comparable and have been omitted. 


\section{$5 \quad$ Backfill characteristics}

In addition to capturing the pressures acting on the barricade, instrumentation programs also capture the characteristics of the backfill. The following section will summarise the characteristics of:

- Constrained thermal expansion and contraction.

- Time to onset of effective stress.

- Time to non-hydrostatic loading.

- Effect of flushes.

- Effect of seismicity and blasting.

\subsection{Constrained thermal expansion and contraction}

Constrained thermal expansion is a phenomenon caused by thermal expansion of backfill material within the confined stope volume with rigid sidewalls (either rock or cured backfill), which was first identified within backfill by Thompson et al. (2014a). Oke et al. (2021a) identified both the expansion and contraction phenomenon. The factors that contribute to the thermal expansion/contraction and the resulting change of pressure on the instruments are:

- Instrument configuration design.

- Binder type.

- Binder content.

- Water content.

- Air content.

- Geometry of the stope.

- Elastic modulus of the rock mass.

At this point in time there is no possible way to predict the extent of expansion or contraction the in situ backfill will undergo as a result of thermal changes. Case studies where thermal expansion was observed include Coleman Mine (Thompson et al. 2014b) and the Garson Ramp mine (Thompson et al. 2014a). Both thermal expansion and contraction were observed at Red Lake operations (Oke et al. 2021a).

\subsubsection{Coleman Mine}

A previously unpublished study at Coleman Mine (2013) found that an instrument was constrained by the $\mathrm{CHB}$ and the resulting thermal expansion effects saw an increase in pressure readings, as shown in Figure 3. At the end of the plug pour for stope 1610, the horizontal stress measurement read $225 \mathrm{kPa}$ on the top third of the barricade. Over the course of a three-day cure period, an increase in temperature of $1-2^{\circ} \mathrm{C}$ was registered. This increase in temperature resulted in a pressure increase of $50 \mathrm{kPa}$ acting on the barricade for a total of $275 \mathrm{kPa}$ by the end of the cure period for the plug pour. It is important to note that horizontal pressure instruments installed lower on the barricade only saw a $\sim 10 \mathrm{kPa}$ increase for a total pressure reading of $85 \mathrm{kPa}$. This difference in pressure reading could be attributed to the segregation affect, as discussed earlier.

An additional study at Coleman Mine (stope 1612) found that thermal expansion resulted in a pressure reading of $173 \mathrm{kPa}$ in the instrument installed at the top of the barricade and $154 \mathrm{kPa}$ at the bottom measurement location. However, after this initial thermal expansion there was a significant decrease in pressure (possible thermal contraction/dissipation). This thermal expansion and contraction had occurred during the pouring process. Before the end of the pour, the top measurement decreased to $75 \mathrm{kPa}$ before spiking to $243 \mathrm{kPa}$. Similarly, about seven hours later, the bottom instrument decreased to $-2 \mathrm{kPa}$, then spiked 
to $59 \mathrm{kPa}$. The difference between the two spikes of pressure was the porewater pressure. The top measurement recorded a large spike of pore pressure (32-140 kPa) whereas the bottom instrument only saw a small spike of pore pressure $(-8-11 \mathrm{kPa})$. Therefore, the magnitude of the spike of pressure was caused by porewater pressure (i.e. additional water was added to the system). The addition of water was not able to be quantified as backfill pour times were not recorded.

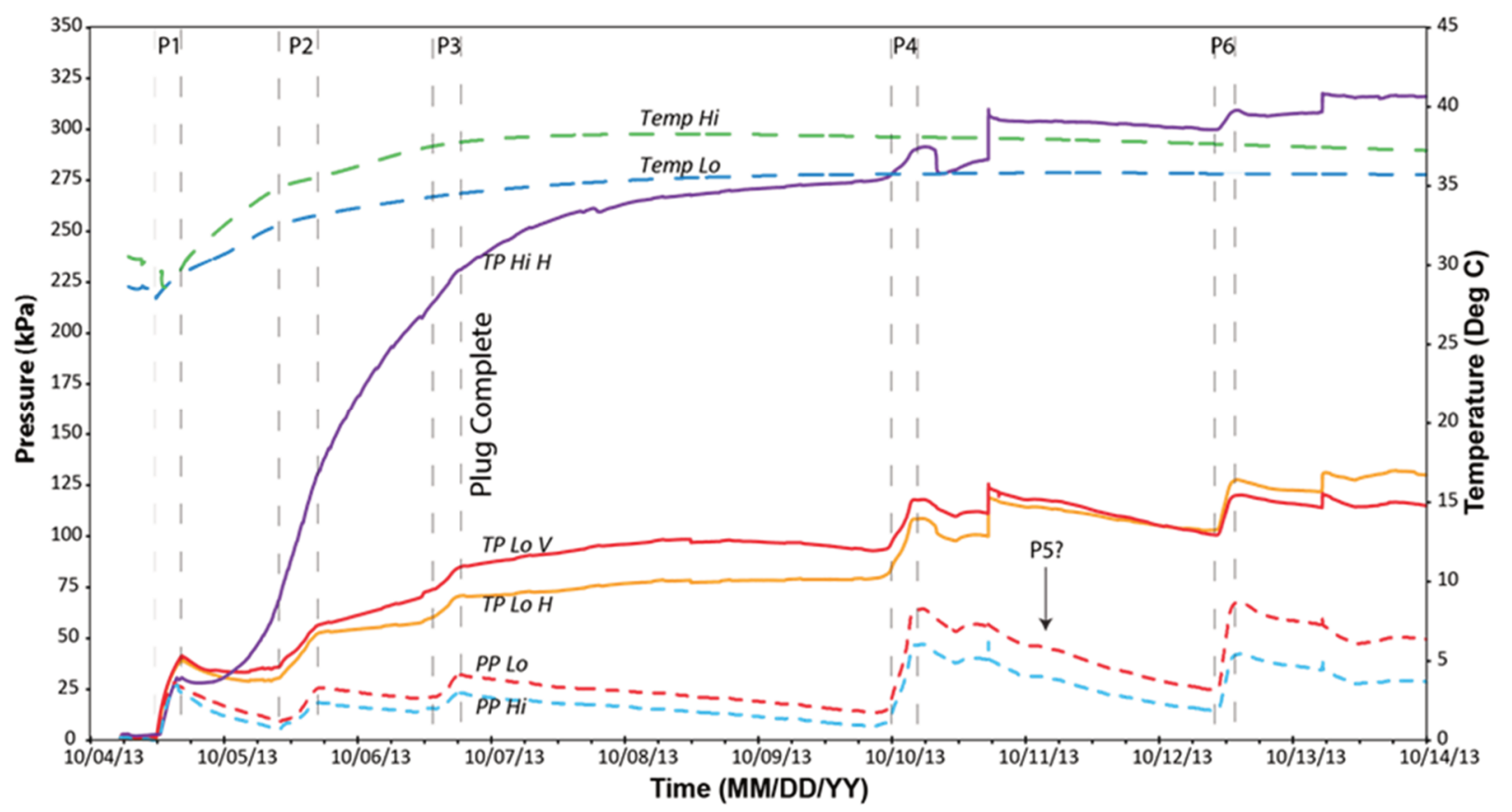

Figure 3 Data from 10 days of backfilling at Coleman Mine stope 1610. Pressure (total pressure, TP and pore pressure, PP) are displayed for the low (Lo) and high (Hi) barricade locations. The Lo instruments measure both vertical $(\mathrm{V})$ and horizontal $(\mathrm{H})$ total pressures. Temperatures are also measured at all instruments. Various pours are marked by the dashed lines

Stope 1612 of Coleman Mine captures a spike of pressure followed by an expansion and contraction for the top barricade and three spikes followed by a contraction on the bottom barricade, as shown in Figure 4 prior to the completion of the plug. It is important to note between 6 and 9 April the pressure is decreasing while backfill is being added to the system (backfill times and duration were not recorded). The drop in pressure was not correlated to blasting events. It was hypothesised that the slow decrease of pressure drop was not completely caused by thermal contraction, and was partially caused by deformation of the barricade, as the pressures measured on the barricade was close to the barricade design pressure limits. However, there was no major concern for the barricade stability at Coleman Mine, as the backfill plug had been curing for seven days at the time of the greatest pressure spike $(280 \mathrm{kPa})$. 


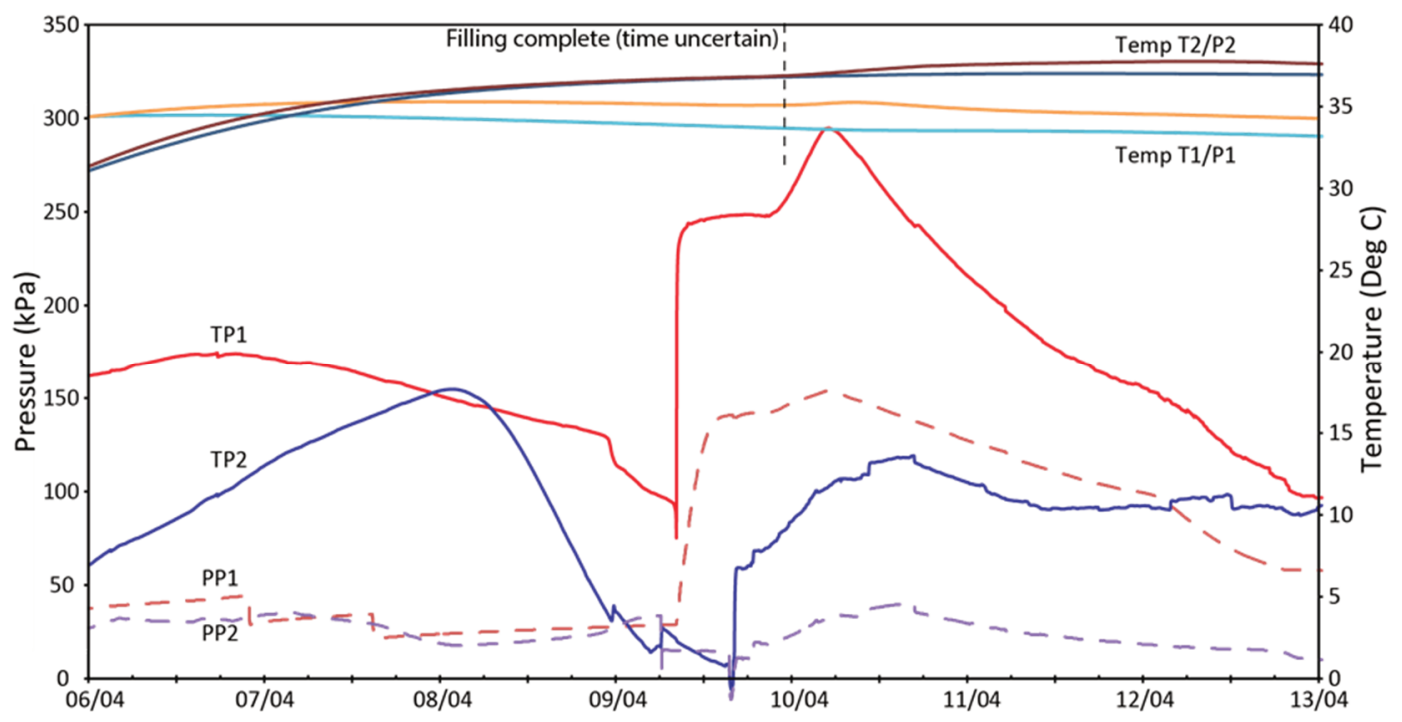

Figure 4 Results from Coleman Mine stope 1612. Pressure (total pressure, TP and pore pressure, PP) are displayed for the low and high ( 1 and 2 respectively) barricade locations. Temperatures are also measured at all instruments. This period is characterised by unusual changes in both TP and PP

\subsubsection{Garson Ramp mine}

Thompson et al. (2014b) captured the constrained thermal expansion phenomenon within hydraulic fill. Figure 5 illustrates the phenomenon at Garson Ramp, measured from instrumentation on the barricade. The instruments read an additional $40 \mathrm{kPa}$ of pressure, assumed to be caused by thermal expansion, between the end of the plug pour (pour \#5) and the start of the main pour (pour \#6), with less than $1^{\circ} \mathrm{C}$ temperature change.

a) Garson Ramp Barricade Test 1, 5 days of monitoring

b) Garson Ramp Barricade Test 1, 14 days of monitoring
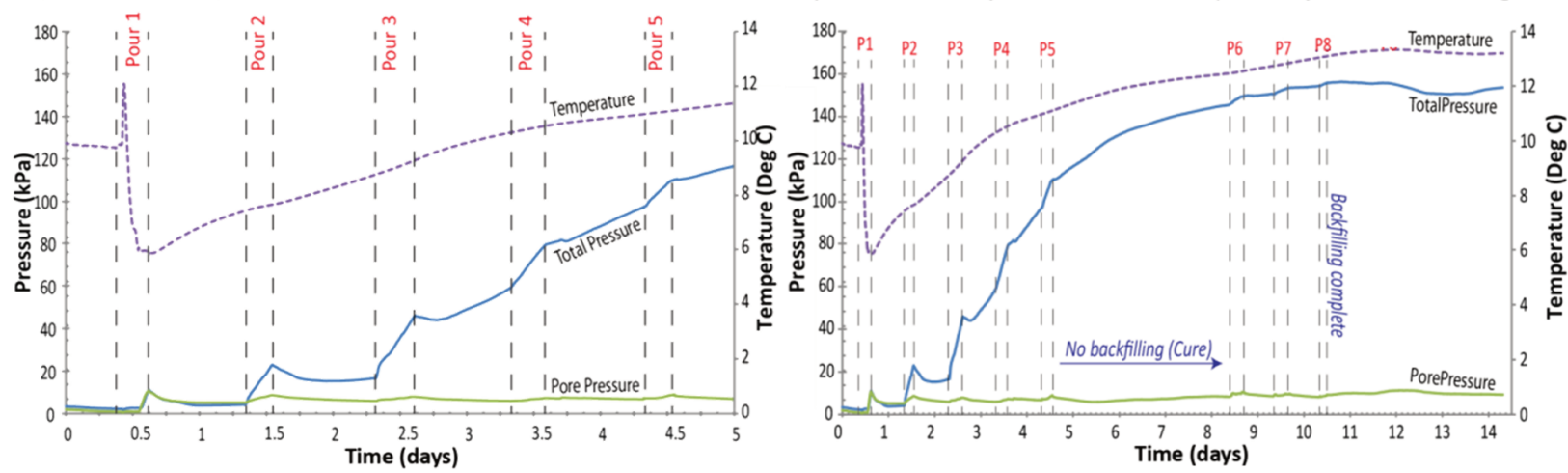

Figure 5 Total earth pressures, pore pressure and temperature measured for the 880-6514 stope at Garson Ramp for five-day and 14-day periods. Modified after Thompson et al. (2014b)

Similarly, measurements within the brow and in an additional stope at Garson Ramp found that there was thermal expansion pressures of 100-125 kPa between the end of the plug pour and the start of the main pour, with less than a $2^{\circ} \mathrm{C}$ temperature change. Thermal expansion was also identified in the instrumentation following three main pours. The final three pours (for a total of six) either saw the pressure being stabilised or decreasing.

\subsubsection{Kidd and Williams mine}

Thompson et al. (2014a) looked into the phenomenon of constrained thermal expansion on pressure cells at Kidd mine and Williams mine. Thermal expansions was observed in high binder content ( $>4 \%$ binder) within CPB. However, when binder was reduced to $2.25 \%$, the phenomenon was not captured. Similarly, at Williams 
mine a $3 \%$ binder of $\mathrm{CPB}$ did not capture the phenomenon, even with a $6^{\circ} \mathrm{C}$ temperature change. These $\mathrm{CPB}$ results indicate that the thermally correlated pressure increase is dependent on the properties of the backfill materials.

Thompson et al. (2014a) shows that the highest thermal expansion on pressure cells recorded at Kidd mine, saw an increase of pressure rate of $20-30 \mathrm{kPa} /{ }^{\circ} \mathrm{C}$. The influence of geometry, material properties of the cell, and elastic modulus of the surrounding rock were theoretically accounting for $0.9-1.4 \mathrm{kPa} /{ }^{\circ} \mathrm{C}$. Simple lab tests indicate that instrumentation could account for $0.4-0.5 \mathrm{kPa} /{ }^{\circ} \mathrm{C}$. Lab tests on the $\mathrm{CPB}$, to study the effects of thermal expansion on the water, air, and other materials within the sample saw $4-10 \mathrm{kPa} /{ }^{\circ} \mathrm{C}$. The difference between field and laboratory values could be due to numerous variables. The most significant may be the difference in stiffness of CPB during testing; i.e. lab testing samples are heated externally immediately after preparation, whereas samples in the field have a temperature increase due to cement hydration.

\subsubsection{Red Lake operations}

Strong evidence of thermal expansion and contraction has been recorded during the monitoring at Red Lake operations as stated in Oke et al. (2021a). Three of the four stopes instrumented captured this phenomenon. The backfilling work used CPB with a 5 or $9 \%$ binder for the plug pour followed by a $3 \%$ binder for the main pour. Data were collected for 31 days after the stope was completely filled. Table 5 provides a review of both the expansion and contraction captured by the instruments. For additional information for thermal expansion and contraction captured at RLO, refer to Oke et al. (2021a).

Table 5 Rates of recorded expansion and contraction at RLO (Oke et al. 2021a)

\begin{tabular}{lllll}
\hline Stope & Binder (\%) & Expansion $\left(\mathrm{kPa} /{ }^{\circ} \mathrm{C}\right)$ & \multicolumn{2}{c}{ Contraction $\left(\mathrm{kPa} /{ }^{\circ} \mathrm{C}\right)$} \\
& & & In-stope & Fill fence \\
\hline $321-865-1$ W Blk3 & 5 & - & - & - \\
$260-876-1$ Blk1 & 5 & $6-26$ & $18-25$ & $4-22$ \\
$512-595-1 E$ Blk3 & 9 & $4-9.3$ & $17-28$ & $3.2-15$ \\
$192-979-1 E$ Blk4 & 9 & $14-23$ & $19-35$ & $18-22$ \\
\hline
\end{tabular}

\subsubsection{Summary and discussion}

All backfill will have some effects of thermal expansion or contraction. Understanding these effects are important for barricade stability and backfill placement. If a plug has been poured and cured for the allocated time, and the main pour results in the barricade cracking, there could be two driving factors:

- Thermal expansion: If thermal expansion occurs within the plug, extensive pressure would be acting on the barricade. The addition of the main pour could be the additional stress necessary to generate cracks in the barricade, however, thermal expansion cannot take place unless there is significant strength gain. Typically, this strength gain is adequate enough to resist the main pour load, in which case the barricade is no longer necessary.

- Low CPB strength: If the backfill is curing slowly resulting in a low CPB strength, then the addition of the main pour could result in the barricade and the plug to completely fail.

Based on the current database and understanding, there is no way to predict the magnitude of the thermal expansion or contraction. The only way to capture these effects is through an in situ instrumentation program. 


\subsection{Time to onset of effective stress}

It is common (almost universal) in both hydraulic and CPB backfilling that total stress and porewater pressure are identical during the initial pouring stages. This is because the backfill is delivered as a slurry (even CPB is arguably a high-density slurry), and effective stresses do not develop between the tailings grains. Once the water starts to drain and the tailings grains come into contact and transmit stress, the porewater pressure no longer increases as quickly as the total stress and, therefore, effective stress is quantified as the difference between these two measurements. Early onset of effective stress is a positive indicator that the backfill is gaining shear strength and stiffness. This promotes arching effects within stope sidewalls and reduces the vertical stress as compared to a one-dimensional deposition environment (i.e. for which the vertical stress is equal to the backfill's unit weight multiplied by the height of material above the point of interest). The following examples demonstrate identification of effective stress development from previous backfill monitoring programs.

\subsubsection{Coleman Mine}

A study at the Coleman Mine found that it took 1.5 hours of continuous pouring of $\mathrm{CHB}$ for the instrumentation to identify that the porewater pressure diverged and presented a lower pressure than the total earth pressure cells (TEPCS) measuring the horizontal and vertical stresses. It is important to note that these instruments were installed on a barricade within a drawpoint.

\subsubsection{Garson Ramp mine}

Garson Ramp typically poured their CHB plugs in five lifts with drainage periods between each lift pour, and so one of the objectives of the instrumentation study was to pour the plug continuously and monitor in real time to determine if the pour needed to be stopped or not. For the cages installed within the stope and under the brow, it was shown that after three hours of continuous pouring, the porewater pressure diverged and presented a lower pressure than the TEPC being measured in the horizontal and vertical direction (Figures $6 b \& 6 c$ ). At the barricade, less than one hour was required to see the porewater pressure diverge (Figure 6a).

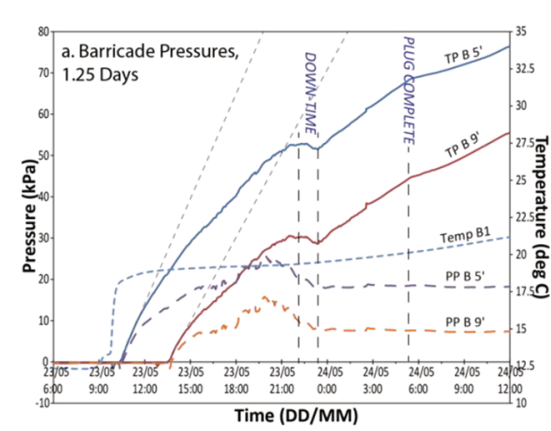

(a)

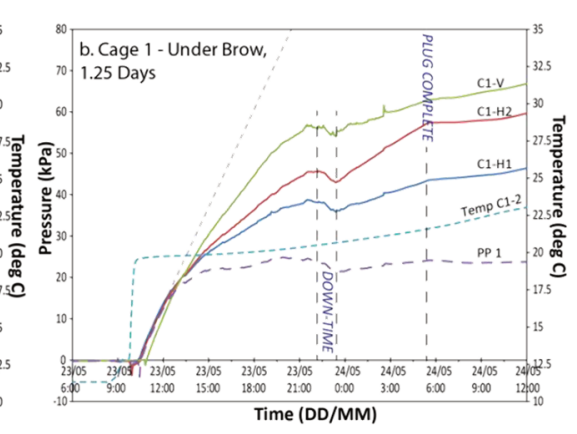

(b)

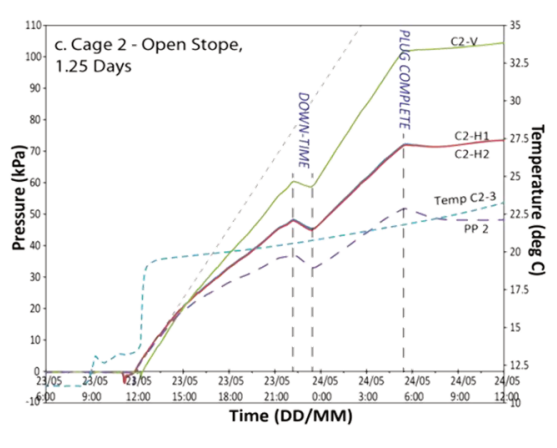

(c)

Figure 6 Total pressure, pore pressure (PP) and temperature data measured during the Garson 880-6514 stope. (a) Total pressures at the barricade (TP B) are measured at 1.5 and $2.7 \mathrm{~m}$ elevations; (b \& c) Vertical total pressures $(\mathrm{V})$ and horizontal total pressures ( $\mathrm{H} 1$ and $\mathrm{H} 2$ ) for instrument cages (C1 or C2). Modified after Thompson et al. (2014b)

\subsubsection{Red Lake operations}

As indicated in Table 4, four stopes were monitored during the instrumentation program at RLO. The fastest time required for the shear strength gain was achieved in the 321-865-1W BLK3 stope, where about two hours after the instruments at the bottom of the stopes were covered with CPB, pore pressures dropped indicating that the backfill is consolidating. The 192-979-2E BLK4 stope experienced the longest time to the onset of shear strength gain where it took about five hours for the CPB to see porewater pressures to drop. 
The time difference for the onset of shear strength gain could be attributed to the geometry of the stopes where, in narrower stopes, stress arching is expected to form earlier than in wider stopes. Effective water drainage would also contribute to accelerating the onset of shear strength gain, as indicated earlier. Early-age CPB strength testing was conducted on both of these stopes, and the results indicated the opposite response, with the 9\% binder (192-979-2E BLK4) capturing faster and stronger cure times than the 5\% binder (192-979-2E BLK4) plug. This is an ideal example of why in situ instrumentation testing should be conducted, in order to capture the in situ CPB behaviour.

\subsubsection{Summary}

To be able to capture the time of onset to effective stress, the pour needs to be continuous after the instrumentation has been covered. For CHB, this can be difficult as periods of dewatering are necessary.

\subsection{Time to non-hydrostatic loading}

The time to non-hydrostatic loading occurs when the horizontal pressures diverge from the vertical pressures. This typically occurs at or shortly after effective stresses are developed. Similarly, the time to initial drop of pore pressure is difficult to capture as it can fall within the cure/drainage period for $\mathrm{CHB}$. Time to non-hydrostatic loading is important as it is an indication that shear stresses are actually developed within the CPB (i.e. strength gain) and stress arching is taking place. The degree of arching in a stope depended on the ratio $A / V$, where $A$ is the wall area per unit height of the stope and $V$ is the stope volume per unit height (Helinski et al. 2011).

Non-hydrostatic conditions can only truly be measured if three TEPC instrumentations are positioned orthogonally to each other (i.e. one vertically, and two horizontally). Initial instrumentation programs should include an orthogonal TEPC instrumentation cluster to identify the time to non-hydrostatic loading. Then, once this time frame is well understood (three to five tests), only one TEPC instrumentation is required to be installed (measure in the direction of the barricade pressure). The authors have only one case study where a $\mathrm{CHB}$ pour was continuous enough that the non-hydrostatic loading was captured within the instrumentation data.

\subsubsection{Garson Ramp mine}

A study at Garson Ramp (Thompson et al. 2014b) found that non-hydrostatic conditions were found four hours after the instruments were covered in backfill (Figures $6 \mathrm{~b}$ and $6 \mathrm{c}$ ). This is the only case study in CHB that captured this effect.

\subsubsection{Red Lake operations}

The onset of non-hydrostatic loading for three of the four stopes of RLO were similar to the onset of effective stresses meaning the horizontal pressure readings diverged from the vertical pressures at approximately the same time as when the porewater pressures dropped. The exception was stope 260-876-1 BLK1, where the horizontal pressures diverged from vertical pressure two hours after the porewater pressures dropped, meaning the onset of non-hydrostatic loading occurred approximately six hours after the in-stope instrument was covered with CPB. The slower divergence from hydrostatic loading for stope 260-876-1 BLK1 could possibly be explained by the lower binder content (typically slower strength gain), however 321-865-1W Blk 3 had the same binder content and early-age CPB strength results, indicating it had the slowest strength gain. Therefore, additional factors (such as composition of tailing or stope geometry) could be influencing the results.

\subsubsection{Cayeli mine}

Thompson et al. (2012) identified one case at Cayeli mine (stope 685) with CPB that took 14 hours for non-hydrostatic conditions to be developed. However, stope 715 had a longer time to non-hydrostatic condition, but the instrumentation pressure exceeded the allowable pressure, so the pour was stopped for 
three days. The major difference between the two stopes is that clastic tails were used for the 685 stope and non-clastic tails were used for the 715 stope. The 685 stope, non-clastic tailings showed a rapid temperature gain. The 715 stope, clastic tailings showed a 2.6-day delay before temperature increased. The delay in temperature response of the 715 stope's backfill is likely due to delayed cement hydration, presumably from differences in the geotechnical properties or chemistry between the two tailings streams. For further differences between these two stopes, refer to Thompson et al. (2012).

There is an aspect which was not considered within the Thompson et al. (2012) interpretation pertaining to the solid concentration (mass [m] and volume [v]) of the two backfills: $79.4 \% \mathrm{~m}$ for stope 685 and $81.3 \% \mathrm{~m}$ for stope 715 . This corresponds to $46 \% \mathrm{v}$ and $49 \% \mathrm{v}$, respectively. In addition, the unit weight of the backfill is $26 \mathrm{kPa} / \mathrm{m}$ for stope 685 and $27 \mathrm{kPa} / \mathrm{m}$ for stope 715 .

\subsection{Effects of flushes}

A flush is a large quantity of water used to clear solids from the fill borehole/pipeline at the end of the fill pour. This additional water can result in a spike of pore pressure, which in turn increases the total pressure. The CHB case studies do not show any major impact of a flush.

\subsubsection{Red Lake operations}

The recorded backfill instrumentation data captured some pressure spikes after a flush at RLO. In the case of stope 321-865-1W BLK3, these flush spikes varied from 2 to $20 \mathrm{kPa}$. The highest flush pressure spike occurred at the end of the pour which caused a $20 \mathrm{kPa}$ increase in vertical pressure, and 12 to $17 \mathrm{kPa}$ for horizontal stress measurements for the in-stope instrument cluster. This is an indication that, even at the end of the pour, the plug region was still responsive to excessive water placement; however, there was no indication of pressure spikes due to flushes were recorded in stope 260-876-1 BLK1. In the case of stope 512-595-1E BLK3, small spikes varying from 3 to $7 \mathrm{kPa}$ were registered during flushes. Minor pressure flush spikes of $\sim 5 \mathrm{kPa}$ were also registered while monitoring stope 192-979-2E BLK4.

\subsubsection{Summary}

The backfill database indicated that in CPB it is typical to see a 10-20 kPa spike of pressure when a flush occurs, but a measured spike as high as $80 \mathrm{kPa}$ for a total pressure of $100 \mathrm{kPa}$ acting on the barricade has occurred at an unpublished mine site. This illustrates the importance of controlling the flush volume, and if excessive flushing is required, a contingency plan to divert the flush volume away from the recently backfilled stope.

\subsection{Effects of seismic/blasting events}

The effects of seismic events and blasting events can result in an increased pressure spike caused by a fall of ground, closure of the stope opening, or a seismic wave re-liquefying the backfill. It is important to note that if a mine-induced seismic event (e.g. blast) is too short to be able to re-liquefy the CPB is still up to debate. Additionally, the amount of increased pressure will be influenced by the current strength and stiffness of the backfill and the proximity of the event to the stope being backfilled.

\subsubsection{Coleman Mine}

A study at Coleman Mine had a blasting event four days after the CHB plug was cured, and 12 hours after the first main pour. These blasting events resulted in a $25 \mathrm{kPa}$ spike on TEPC instrumentation installed on the barricade. It is important to note that these instruments were installed on a barricade within a drawpoint. However, another study at Coleman Mine found that a blast resulted in a $15 \mathrm{kPa}$ decrease in pressure acting on barricade, and a $10 \mathrm{kPa}$ decrease on the pressure within the stope. 


\subsubsection{Kidd mine}

At Kidd mine (Thompson et al. 2014b), a production blast induced a pressure increase of $60 \mathrm{kPa}$ (within CPB) in the horizontal pressure axis in the stope. This pressure spike was assumed to be caused by the stope walls converging into the fill.

\subsubsection{Red Lake operations}

Seismic events were analysed in RLO to correlate pressure spikes to the seismicity events which occurred in the vicinity of the stopes that were instrumented for the purpose of backfill monitoring. In the case of stope 321-865-1W BLK3, eight days after the pouring work was accomplished, a seismic event (moment magnitude -1.15) which was recorded in the blasting time window led to a $14 \mathrm{kPa}$ horizontal pressure increase acting perpendicular to the barricade. In the case of stope 192-979-2E BLK4, one day after the last pour was accomplished, a seismic event with moment magnitude of 0.3 was incurred about $80 \mathrm{~m}$ away from the stope which caused a $\sim 30 \mathrm{kPa}$ drop in the horizontal pressures acting on the barricade.

\subsubsection{Summary}

The influence of seismic and blast events can have varying effects on the backfill. It is not possible to provide ranges of the potential spikes of pressure at this point in time as the effects are data limited. However, as noted in Jafari et al. (2020), the amount of stress within the backfill of a stope, due to a seismic event, will be dependent on the closure and the modulus of the backfill. When backfill has a low modulus (low strength at early stages of cure) the increase in stress due to closure is low compared to when the backfill has a higher modulus (final strength). Therefore, seismic events should have limited effects during the initial pour, when the barricade's capacity is most critical, unless it can re-liquefy the backfill. It is important to note that a seismic wave re-liquefying the backfill has never been observed or reported in the literature. Additionally, there has been no confirmed evidence of backfill or barricade failures caused by seismic/blasting events.

\section{$6 \quad$ Backfill strength testing}

With any backfill instrumentation program, it is recommended that backfill strength also be tested in order to capture the strength-versus-time relationship. For CPB, if a continuous pour strategy is proposed, an early-age strength test is required. Strength testing has been done as early as nine hours on a $5 \%$ binder CPB mixer and shown in Oke et al. (2021a, b). This early-age strength testing allowed for the authors to provide continuous pour backfilling recommendation which included a reduction in exclusion zones based on quality assurance/quality control instrumentation and/or ongoing strength testing. For continuous pouring, the strength of the backfill is required to resist liquefaction by the time the plug volume has been filled, provided the pressures acting on the barricade do not exceed the allowable design pressure.

\section{Conclusion}

This paper summarises the results of case studies from $\mathrm{CHB}$ and $\mathrm{CPB}$ projects. Each project has its own unique findings and backfill characteristics that are important to understand in order to develop effective backfill pour strategies and barricade designs. Backfill instrumentation programs enable the strategy of each mine to be optimised by providing a clearer understanding of their true backfill characteristics.

\section{Acknowledgement}

The first author thanks Dr Bawden, Dr Grabinsky, Mr Lausch, and Dr Thompson for their collaboration in the field of rock mechanics, backfill, and barricade design over the years at RockEng (formally MDEng). Their shared experiences have provided valuable insight into understanding backfill mechanics. 


\section{References}

Alcott, J, Dallaire, D \& Belem, T 2019, 'Pastefill optimisation at Hecla Québec's Casa Berardi mine', Proceedings of the 53rd US Rock Mechanics/Geomechanics Symposium, American Rock Mechanics Association, Alexandria.

Belem, T, Harvey, A, Simon, R \& Aubertin, M 2004, 'Measurement and prediction of internal stresses in an underground opening during its filling with cemented fill', in E Villaescusa \& Y Potvin (eds), Proceedings of the Fifth International Symposium on Ground Support in Mining and Underground Construction, A.A. Balkema, Rotterdam, pp. 28-30.

Grabinsky, MW \& Bawden, WF 2007, 'In situ measurements for geomechanical design of cemented paste backfill systems', Canadian Institute of Mining Bulletin, special edition on mining with backfill.

Grabinsky, MW 2010, 'In situ monitoring for ground truthing paste backfill designs', in R Jewell \& AB Fourie (eds), Paste 2010: Proceedings of the Thirteenth International Seminar on Paste and Thickened Tailings, Australian Centre for Geomechanics, Perth, pp. 85-98, https://doi.org/10.36487/ACG_rep/1063_8_Grabinsky

Grice, T 1998, 'Underground mining with backfill', Proceedings of the 2 nd Annual Summit - Mine Tailings Disposal Systems.

Hassani, F \& Archibald, J 1998, Mine Backfill 1998, Canadian Institute of Mining, Metallurgy and Petroleum, Montreal.

Hasan, A, Suazo, G, Doherty, JP \& Fourie, AB 2014, 'In situ measurements of cemented paste backfilling in an operating stope at Lanfranchi Mine', in Y Potvin \& T Grice (eds), Proceedings of the Eleventh International Symposium on Mining with Backfill, Australian Centre for Geomechanics, Perth, pp. 327-336, https://doi.org/10.36487/ACG_rep/1404_26_Hasan

Helinski, M, Fahey, M \& Fourie, A 2011, 'Behavior of cemented paste backfill in two mine stopes: measurements and modeling', Journal of Geotechnical and Geoenvironmental Engineering, vol. 137, no. 2, pp. 171-182.

Jafari, M, Shahsavari, M \& Grabinsky, M 2020, 'Cemented paste backfill 1-D consolidation results interpreted in the context of ground reaction curves', Rock Mechanics and Rock Engineering, vol. 53, no. 9, pp. 4299-4308.

Le Roux, K, Bawden, WF \& Grabinsky, MW 2005, 'Field properties of cemented paste backfill at the Golden Giant mine', Mining Technology, vol. 114, no. 2, pp. 65-80.

Oke, J, Hawley, K, Belem, T \& Hashemi, A 2021a, 'Paste backfill thermal contraction: Red Lake operations case study', in AB Fourie \& D Reid (eds), Paste 2021: Proceedings of the 24th International Conference on Paste, Thickened and Filtered Tailings, Australian Centre for Geomechanics, Perth, pp. 425-438.

Oke, J, Hawley, K, Belem, T \& Hashemi, A 2021b, 'Paste backfill continuous pour: Red Lake operations case study', in AB Fourie \& D Reid (eds), Paste 2021: Proceedings of the 24th International Conference on Paste, Thickened and Filtered Tailings, Australian Centre for Geomechanics, Perth, pp. 381-396.

Potvin, Y, Thomas, E \& Fourie, AB 2005, Handbook on Mine Fill, Australian Centre for Geomechanics, Perth.

Thompson, BD, Grabinsky, MW, Bawden, WF \& Counter, DB 2009, 'In-situ measurements of cemented paste backfill in long-hole stopes', in M Diederichs \& G Grasselli (eds), Proceedings of the 3rd CANUS Rock Mechanics Symposium, pp. 197-198.

Thompson, BD, Bawden, WF \& Grabinsky, MW 2011, 'In situ monitoring of cemented paste backfill pressure to increase backfilling efficiency', CIM Journal, vol. 2, no. 4, pp. 1-10.

Thompson, BD, Bawden, WF \& Grabinsky, MW 2012, 'In situ measurements of cemented paste backfill at the Cayeli Mine', Canadian Geotechnical Journal, vol. 49, no. 7, pp. 755-772.

Thompson, BD, Simon, D, Grabinsky, MW, Counter, DB \& Bawden, WF 2014a, 'Constrained thermal expansion as a causal mechanism for in situ pressure in cemented paste and hydraulic backfilled stopes', in Y Potvin \& T Grice (eds), Proceedings of the 11th International Symposium on Mining with Backfill, Australian Centre for Geomechanics, Perth, pp. 365-378, https://doi.org/10.36487/ACG_rep/1404_29_Thompson

Thompson, BD, Hunt, T, Malek, F, Grabinsky, MW \& Bawden, WF 2014b, 'In situ behaviour of cemented hydraulic and paste backfills and the use of instrumentation in optimising efficiency', in Y Potvin \& T Grice (eds), Proceedings of the 11th International Symposium on Mining with Backfill, Australian Centre for Geomechanics, Perth, pp. 337-350, https://doi.org/ 10.36487/ACG_rep/1404_27_Thompson

Yang, P 2016, Investigation of the Geomechanical Behavior of Mine Backfill and its Interaction with Rock Walls and Barricades, doctoral dissertation, École Polytechnique de Montréal, Montreal.

Yumlu, M 2001, 'Backfill practices at Çayeli mine', in E Ünal, B Ünver \& E Tercan (eds), Proceedings of the 17th International Mining Congress and Exhibition of Turkey, The Chamber of Mining Engineers of Turkey, Ankara, pp. 333-339. 